\title{
The confidence of undergraduate dental students in Saudi Arabia in performing endodontic treatment
}

Mothanna Alrahabi ${ }^{1}$

Correspondence: Dr. Mothanna Alrahabi

Email: mrahabi@taibahu.edu.sa
'Department of Restorative Dentistry Science, College of Dentistry, Taibah University, Al Madinah Al Munawwarah, Saudi Arabia

\section{ABSTRACT}

Objective: This study examined the endodontic experience, perceptions of endodontic practice, and self-rated confidence of dental students enrolled in Taibah University, Saudi Arabia. Materials and Methods: A questionnaire was distributed to 41 undergraduate dental students registered in endodontic courses in the 2015 academic year. The questionnaire evaluated their confidence performing nonsurgical root canal treatment. The level of confidence was classified using a 5-point scale as "very confident," "confident," "neutral," "not very confident," or "not at all confident." The data were analyzed using SPSS version 20.0 (SPSS, Chicago, IL, USA). Results: The participation rate was 93\%. The maxillary incisor was the most common first tooth treated. The students were relatively confident, but their confidence levels were lower regarding endodontic radiology, evaluation of root canal obturation, and determining the correct recall period for the patient. Conclusion: The confidence of undergraduates in endodontics must be enhanced to increase their clinical competence when performing root canal treatment.

Key words: Dental students, education, endodontics, Saudi Arabia, self-confidence

\section{INTRODUCTION}

Student perception of their dental school experience is an essential measure of the success of dental education. ${ }^{[1]}$ Undergraduates' feedback and suggestions are very important for improving the curriculum and learning process. ${ }^{[2]}$ This information also helps determine the students' preferences regarding different elements of their educational experience. ${ }^{[3]}$ Low self-confidence affects the daily practice of health professionals. ${ }^{[4-8]}$ Endodontics teaching can be considered complex, difficult, and stressful because of the complex anatomy of the root canal system, responsibility toward patients, and low self-confidence. Many students feel inadequate in terms of endodontic molar treatments. ${ }^{[1]}$ However, teaching endodontics in recent years has improved as a result of the development of knowledge,

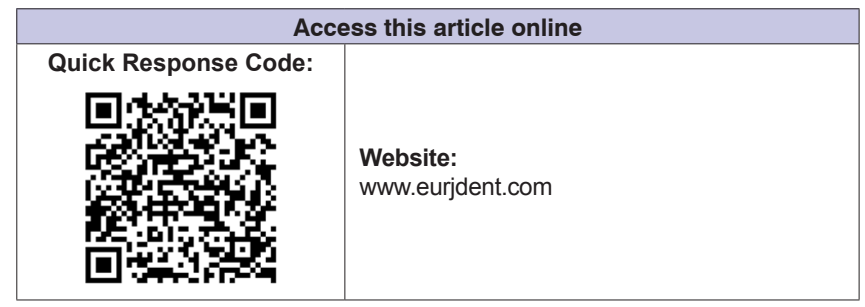

techniques, and materials. ${ }^{[9]}$ Dental students at Taibah University, Saudi Arabia, take a preclinical full-year endodontic course in the $3^{\text {rd }}$ year of their 6-year Bachelor of Dental Surgery degree. The course consists of $28 \mathrm{~h}$ of theoretical lectures and 28 3-h laboratory sessions, during which they perform technical aspects of root canal treatment on extracted single- and multi-rooted teeth. There is a one-semester clinical endodontic course in the $4^{\text {th }}$ year that consists of 14 theoretical lectures and fourteen 3-h clinical sessions during which students treat single- and multi-rooted teeth. In the $5^{\text {th }}$ year, endodontic treatments are performed as part of a comprehensive dentistry care course under the supervision of specialists. This curriculum

This is an open access article distributed under the terms of the Creative Commons Attribution-NonCommercial-ShareAlike 3.0 License, which allows others to remix, tweak, and build upon the work non-commercially, as long as the author is credited and the new creations are licensed under the identical terms.

For reprints contact: reprints@medknow.com

How to cite this article: Alrahabi M. The confidence of undergraduate
dental students in Saudi Arabia in performing endodontic treatment. Eur J
Dent 2017;11:17-21.
DOI: $10.4103 /$ ejd.ejd_190_16


is consistent with the recommendations of the European Society of Endodontology. ${ }^{[10]}$

This study examined the endodontic experiences, perceptions of endodontic practice, and self-rated confidence of dental students enrolled in Taibah University, Saudi Arabia.

\section{MATERIALS AND METHODS}

Study approval was obtained from the Research Ethics Committee of the College of Dentistry, Taibah University (reference number: TUCDREC/20160107/ ALRAHABI). This study enrolled 41 undergraduate dental students registered in endodontic courses in the 2015 academic year at the College of Dentistry, Taibah University, Saudi Arabia. Participation was voluntary, and students were informed that they could refuse participation.

A questionnaire was distributed to $194^{\text {th }}$-year and $255^{\text {th }}$-year students in the final month of the academic year after they had had the maximum amount of training. The study was briefly described to the participants. The questionnaire consisted of 18 multiple-choice and open-ended questions. The questions evaluated self-confidence at performing nonsurgical root canal treatment and experiences in this discipline. The level of confidence was classified using a 5-point scale as "very confident," "confident," "neutral," "not very confident," or "not at all confident."

To compare results, the Chi-square test and Mann-Whitney U-test were used. Statistical analyses were carried out using SPSS version 20.0 (SPSS, Chicago, IL, USA). Statistical significance was set at $P<0.05$.

\section{RESULTS}

The overall response rate was $93 \%$, with 18 of the $194^{\text {th }}$-year students and 23 of the 25 final-year students returning questionnaires. Table 1 shows the results for the first three questions (first endodontic case treated, level of case difficulty, and number of endodontic treatments performed by the student). The results of the remaining questions are summarized in Table 2. Figure 1 shows levels of confidence in the practical steps of root canal treatment.

Confidence levels differed significantly between $4^{\text {th }}$ - and $5^{\text {th }}$-year students in the following steps of root canal treatment: determining the working length, taking and interpreting radiographs during root canal treatment, evaluating the quality of root canal obturation, and recalling the patients periodically in the correct manner. Fourth-year students were more confident regarding these practical steps than $4^{\text {th }}$-year students.

Table 3 summarizes the results of the last question regarding suggestions to improve the teaching of endodontic courses.

\section{DISCUSSION}

In dentistry, evaluating competence is an important step toward validating the quality of graduating dentists, although the relationship between the self-confidence and clinical competence of medical students is not fully understood. ${ }^{[11]}$ Increasing the confidence of medical students should increase their competence in clinical practice. ${ }^{[12]}$

One way to standardize education is to poll students using questionnaires to help in the assessment, evaluation, and improvement of education. ${ }^{[13]}$ This study obtained information about the confidence of undergraduate dental students at Taibah University, Saudi Arabia regarding endodontics. It revealed that an upper incisor $78 \%$ was the most common tooth first treated by students. Upper incisor root canal treatment is relatively easy, and this should encourage students. In another study, the first teeth treated by students were the first and second maxillary premolars. ${ }^{[14]}$ Most of our students described the experience with the first case as okay $78 \%$, while $7.4 \%$ described it as easy and $14.6 \%$ described the first case as difficult, possibly because the first case for those students involved a molar or premolar. In other studies, students considered molars to be the most difficult tooth to treat. ${ }^{[14-16]}$

In our study, the maximum number of teeth treated in the $4^{\text {th }}$ year was four cases, by $66.7 \%$ of the students, while the maximum number of teeth treated in $5^{\text {th }}$ year was 11 cases, by $8.8 \%$ of the students. The number of teeth treated by students in the $4^{\text {th }}$ and $5^{\text {th }}$ year did not meet the recommendations of the European Society of Endodontology 2001 guidelines, which advised that for adequate competency a student should complete root canal treatments in 20 teeth. ${ }^{[17]}$ Although the European Society of Endodontology published new undergraduate curriculum guidelines for Endodontology in 2013, these focused on the quality 
Alrahabi: Confidence of dental students in endodontic treatment

\begin{tabular}{|c|c|c|c|c|c|c|c|}
\hline \multicolumn{2}{|c|}{ First endodontic case treated } & \multicolumn{3}{|c|}{ Level of first case difficulty } & \multicolumn{3}{|c|}{$\begin{array}{l}\text { Number of endodontic treatments performed by the } \\
\text { student }\end{array}$} \\
\hline Tooth type & Percentage & Easy (\%) & Okay (\%) & Difficult (\%) & $\begin{array}{l}\text { Number of } \\
\text { treated teeth }\end{array}$ & $\begin{array}{c}\text { Fourth academic } \\
\text { year }(\%)\end{array}$ & $\begin{array}{l}\text { Fifth academic } \\
\text { year }(\%)\end{array}$ \\
\hline Upper incisor & 78.0 & 7.4 & 78.0 & 14.6 & 2 & 5.6 & 0 \\
\hline Lower incisor & 7.4 & & & & 3 & 22.2 & 4.3 \\
\hline Upper premolar & 2.4 & & & & 4 & 66.7 & 17.4 \\
\hline Lower premolar & 9.8 & & & & 5 & 5.5 & 17.4 \\
\hline \multirow[t]{4}{*}{ Upper molar } & 2.4 & & & & 6 & 0 & 17.4 \\
\hline & & & & & 7 & 0 & 13.0 \\
\hline & & & & & 8 & 0 & 21.7 \\
\hline & & & & & 11 & 0 & 8.8 \\
\hline
\end{tabular}

\begin{tabular}{|c|c|c|c|c|c|c|c|c|c|c|}
\hline \multirow{2}{*}{$\begin{array}{l}\text { Practical step in } \\
\text { nonsurgical root canal } \\
\text { treatment }\end{array}$} & \multicolumn{2}{|c|}{ Not at all confident } & \multicolumn{2}{|c|}{ Not very confident } & \multicolumn{2}{|c|}{ Neutral } & \multicolumn{2}{|c|}{ Confident } & \multicolumn{2}{|c|}{ Very confident } \\
\hline & $4^{\text {th }}$ year & $5^{\text {th }}$ year & $4^{\text {th }}$ year & $5^{\text {th }}$ year & $4^{\text {th }}$ year & $5^{\text {th }}$ year & $4^{\text {th }}$ year & $5^{\text {th }}$ year & $4^{\text {th }}$ year & $5^{\text {th }}$ year \\
\hline $\begin{array}{l}\text { Diagnosis of cases needing } \\
\text { endodontic treatment }\end{array}$ & 0 & 0 & 5.6 & 13.0 & 50.0 & 30.4 & 16.7 & 43.5 & 27.8 & 13.0 \\
\hline $\begin{array}{l}\text { Knowing when to } \\
\text { refer patients for } \\
\text { more complicated } \\
\text { endodontic treatment }\end{array}$ & 0 & 0 & 11.1 & 13.0 & 33.3 & 47.8 & 44.4 & 34.8 & 11.1 & 4.3 \\
\hline $\begin{array}{l}\text { Achieving anesthesia for } \\
\text { endodontic treatment }\end{array}$ & 0 & 0 & 5.6 & 8.7 & 5.6 & 30.4 & 55.6 & 39.1 & 33.3 & 21.7 \\
\hline Placement of the rubber dam & 0 & 0 & 5.6 & 13.0 & 11.1 & 17.4 & 50.0 & 47.8 & 33.3 & 21.7 \\
\hline $\begin{array}{l}\text { Determining the working } \\
\text { length of each canal using } \\
\text { an electronic apex }\end{array}$ & 0 & 4.3 & 27.8 & 17.4 & 22.2 & 34.8 & 27.8 & 30.4 & 22.2 & 13.0 \\
\hline $\begin{array}{l}\text { Cleaning and shaping } \\
\text { the root canal system }\end{array}$ & 0 & 0 & 0 & 8.7 & 27.8 & 26.1 & 50.0 & 60.9 & 22.2 & 4.3 \\
\hline $\begin{array}{l}\text { Placing an inter-appointment } \\
\text { dressing }\end{array}$ & 0 & 0 & 5.6 & 13.0 & 11.1 & 39.1 & 44.4 & 47.8 & 38.9 & 0 \\
\hline Root canal obturation & 0 & 0 & 5.6 & 17.4 & 22.2 & 34.8 & 50.0 & 39.1 & 22.2 & 8.7 \\
\hline $\begin{array}{l}\text { Understanding and } \\
\text { appropriately managing } \\
\text { the treatment risks } \\
\text { (such as flare-ups) }\end{array}$ & 0 & 13.0 & 33.3 & 26.1 & 38.9 & 43.5 & 22.2 & 17.4 & 5.6 & 0 \\
\hline $\begin{array}{l}\text { Taking and interpreting } \\
\text { pre-, intra-, and } \\
\text { post-operative radiographs }\end{array}$ & 0 & 4.3 & 16.7 & 13.0 & 16.7 & 26.1 & 33.3 & 39.1 & 33.3 & 17.4 \\
\hline $\begin{array}{l}\text { Assessing the quality of a } \\
\text { root filling postoperatively } \\
\text { and determining the correct } \\
\text { recall period for the patient }\end{array}$ & 0 & 0 & 11.1 & 13.0 & 16.7 & 47.8 & 44.4 & 34.8 & 27.8 & 4.3 \\
\hline $\begin{array}{l}\text { Establishing successful } \\
\text { communication with } \\
\text { the patient during the } \\
\text { endodontic treatment }\end{array}$ & 0 & 0 & 0 & 8.7 & 11.1 & 17.4 & 44.4 & 60.9 & 44.4 & 13.0 \\
\hline $\begin{array}{l}\text { Restoration of } \\
\text { endodontically treated teeth }\end{array}$ & 0 & 4.3 & 16.7 & 0 & 27.8 & 21.7 & 33.3 & 60.9 & 22.2 & 13.0 \\
\hline
\end{tabular}

and consistency of student performance more than simply the quantity of clinical exposure. ${ }^{[17]}$ However, one study reported that $81 \%$ of the students in 48 dental schools in the European Union achieved the minimum number of root canal treatments required for their graduation: the number of treated cases ranged between 3 and 80 canals, and the average was

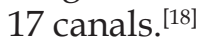




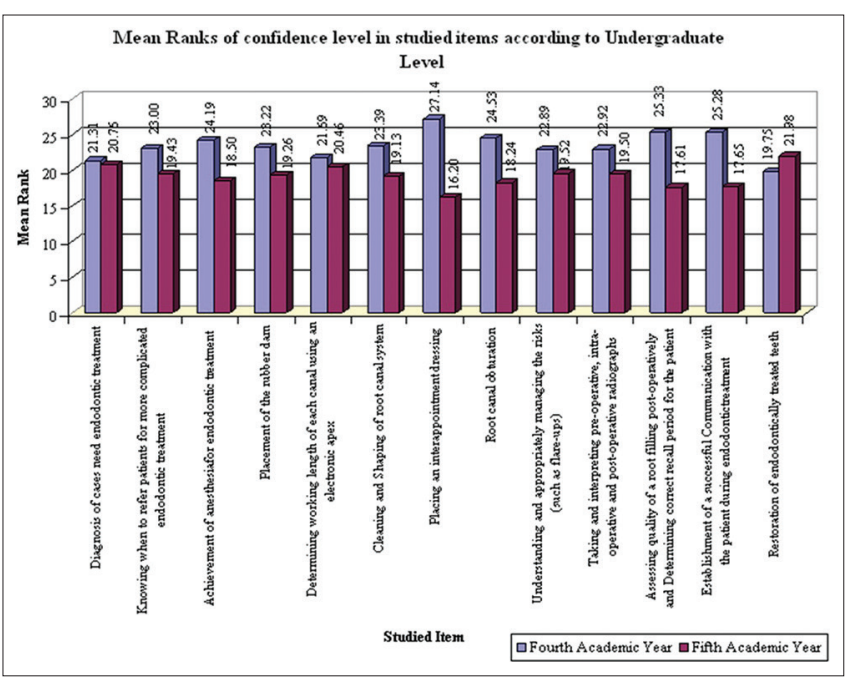

Figure 1: Levels of confidence in the different steps of root canal treatment

\begin{tabular}{lcc}
\hline $\begin{array}{l}\text { Table 3: Students' suggestions for improving the } \\
\text { teaching of endodontic courses }\end{array}$ & \\
\hline $\begin{array}{l}\text { Suggestions to improve } \\
\text { endodontics teaching }\end{array}$ & $\begin{array}{c}\text { Fourth academic } \\
\text { year (\%) }\end{array}$ & $\begin{array}{c}\text { Fifth academic } \\
\text { year (\%) }\end{array}$ \\
\hline $\begin{array}{l}\text { Use rotary nickel-titanium } \\
\text { files during treatment }\end{array}$ & 44.4 & 18.2 \\
$\begin{array}{l}\text { Increase the number } \\
\text { of requirements }\end{array}$ & 5.6 & 9.1 \\
$\begin{array}{l}\text { Extended credit hours } \\
\text { for endodontic courses } \\
\begin{array}{l}\text { Teach a new obturation } \\
\text { technique }\end{array}\end{array}$ & 50.0 & 63.6 \\
\hline
\end{tabular}

In our study, we observed that confidence varied according to both the year the student was in and the practical steps of nonsurgical root canal treatment. Both groups reported relatively good confidence, although there were significant differences between $4^{\text {th }}$ and $5^{\text {th }}$ year students regarding some steps. Fourth-year students were more confident than $5^{\text {th }}$-year students in the following: determining the working length, dealing with X-rays during root canal treatment, evaluating root canal obturation, and recalling patient at the correct time. This might be because there were fewer $4^{\text {th }}$-year students in the sample, there are fewer requirements in $4^{\text {th }}$ year, and strict supervision by supervisors helped $4^{\text {th }}$-year students more than $5^{\text {th }}$-year students.

Confidence regarding working length determination was low in both $4^{\text {th }}$ - and $5^{\text {th }}$-year students. This might be the result of the root canal anatomy, which many dental students find difficult to learn because of its variation among individuals..$^{[1]}$

The reduction in confidence regarding endodontic radiology, the evaluation of root canal obturation, and determining the correct recall period probably results from insufficient clinical exposure. Murray et al. wrote that a lack of clinical exposure in the undergraduate curriculum reduces the confidence that develops with clinical practice. ${ }^{[19]}$ In addition, an overly busy curriculum will compromise self-confidence. ${ }^{[20]}$

Students' suggestions for improving the teaching of endodontics focused on two major issues: using rotary nickel-titanium (NiTi) files during treatment and increasing credit hours for the endodontic course. Introducing advances in endodontics into undergraduate training, such as NiTi rotary instruments, may improve the clinical experience of students and their self-confidence because it will help increase the numbers of cases treated. ${ }^{[1]}$ Peru et al. believe that introducing NiTi rotary instruments into the undergraduate dental curriculum would be safe and improve endodontics teaching ${ }^{[21]}$ because inexperienced operators can learn to use rotary instruments adequately with brief training. ${ }^{[22]}$ Nevertheless, another study found that intensive preclinical training is a prerequisite for using NiTi rotary instruments. These results prompted us to reconsider the theoretical and practical coursework when teaching endodontics. ${ }^{[23]}$

Changing the methods of teaching endodontics so that students can complete root canal treatment more easily and quickly, with minimal procedural accidents, will improve clinical outcomes. ${ }^{[21,24,25]}$ Low self-confidence can be ameliorated by increasing clinical exposure, which will help students to obtain the necessary skills through experience. ${ }^{[6,26]}$

\section{CONCLUSION}

Fourth- and fifth-year dental students at Taibah University, Saudi Arabia, are confident regarding root canal treatment, although they report lower confidence in some steps of the root canal treatment process. Endodontics education should be improved by increasing preclinical and clinical sessions and using new teaching methods that introduce recent advances in endodontics in the undergraduate curriculum.

\section{Financial support and sponsorship}

Nil.

\section{Conflicts of interest}

There are no conflicts of interest. 


\section{REFERENCES}

1. Seijo MO, Ferreira EF, Ribeiro Sobrinho AP, Paiva SM, Martins RC. Learning experience in endodontics: Brazilian students' perceptions. J Dent Educ 2013;77:648-55.

2. Henzi D, Davis E, Jasinevicius R, Hendricson W, Cintron L, Isaacs M. Appraisal of the dental school learning environment: The students' view. J Dent Educ 2005;69:1137-47.

3. Oliver R, Kersten H, Vinkka-Puhakka H, Alpasan G, Bearn D, Cema I, et al. Curriculum structure: Principles and strategy. Eur J Dent Educ 2008;12 Suppl 1:74-84.

4. Birks Y, McKendree J, Watt I. Emotional intelligence and perceived stress in healthcare students: A multi-institutional, multi-professional survey. BMC Med Educ 2009;9:61.

5. Sofola OO, Jeboda SO. Perceived sources of stress in Nigerian dental students. Eur J Dent Educ 2006;10:20-3.

6. Rolland S, Hobson R, Hanwell S. Clinical competency exercises: Some student perceptions. Eur J Dent Educ 2007;11:184-91.

7. Alzahem AM, van der Molen HT, Alaujan AH, Schmidt HG, Zamakhshary MH. Stress amongst dental students: A systematic review. Eur J Dent Educ 2011;15:8-18.

8. Dahan H, Bedos C. A typology of dental students according to their experience of stress: A qualitative study. J Dent Educ 2010;74:95-103.

9. Qualtrough AJ. Undergraduate endodontic education: What are the challenges? Br Dent J 2014;216:361-4.

10. De Moor R, Hülsmann M, Kirkevang LL, Tanalp J, Whitworth J. Undergraduate curriculum guidelines for endodontology. Int Endod J 2013;46:1105-14.

11. Carlisle C. Reflecting on levels of confidence and competence in skills acquisition. Med Educ 2000;34:886-7.

12. Elzubeir MA, Rizk DE. Assessing confidence and competence of senior medical students in an obstetrics and gynaecology clerkship using an OSCE. Educ Health (Abingdon) 2001;14:373-82.

13. Association. B.D. Education: Clinical Audit and Peer Review; 2014. Available from: http://www.bda.org/dentists/education/. [Last accessed on 2014 Aug 07].

14. Murray CM, Chandler NP. Undergraduate endodontic teaching in
New Zealand: Students' experience, perceptions and self-confidence levels. Aust Endod J 2014;40:116-22.

15. Arena G, Kruger E, Holley D, Millar S, Tennant M. Western Australian dental graduates' perception of preparedness to practice: A five-year follow-up. J Dent Educ 2007;71:1217-22.

16. Tanalp J, Güven EP, Oktay I. Evaluation of dental students' perception and self-confidence levels regarding endodontic treatment. Eur J Dent 2013;7:218-24.

17. Lost C. Undergraduate curriculum guidelines for endodontology. Int Endod J 2001;34:574-80.

18. Gatley S, Hayes J, Davies C. Requirements, in terms of root canal treatment, of undergraduates in the European Union: An audit of teaching practice. Br Dent J 2009;207:165-70.

19. Murray FJ, Blinkhorn AS, Bulman J. An assessment of the views held by recent graduates on their undergraduate course. Eur J Dent Educ 1999;3:3-9.

20. Lynch CD, Ash PJ, Chadwick BL. Student perspectives and opinions on their experience at an undergraduate outreach dental teaching centre at Cardiff: A 5-year study. Eur J Dent Educ 2010;14:12-6.

21. Peru M, Peru C, Mannocci F, Sherriff M, Buchanan LS, Pitt Ford TR. Hand and nickel-titanium root canal instrumentation performed by dental students: A micro-computed tomographic study. Eur J Dent Educ 2006;10:52-9.

22. Unal GÇ, Maden M, Orhan EO, Saritekin E, Teke A. Root canal shaping using rotary nickel-titanium files in preclinical dental education in Turkey. J Dent Educ 2012;76:509-13.

23. Alrahabi M. Comparative study of root-canal shaping with stainless steel and rotary NiTi files performed by preclinical dental students. Technol Health Care 2015;23:257-65.

24. Gluskin A, Brown D, Buchanan L. A reconstructed computerized tomographic comparison of $\mathrm{Ni}$-Ti rotary $\mathrm{GT}^{\mathrm{TM}}$ files versus traditional instruments in canals shaped by novice operators. Int Endod J 2001;34:476-84.

25. Sonntag D, Delschen S, Stachniss V. Root-canal shaping with manual and rotary $\mathrm{Ni}$-Ti files performed by students. Int Endod J 2003;36:715-23.

26. Cardall WR, Rowan RC, Bay C. Dental education from the students perspective: Curriculum and climate. J Dent Educ 2008;72:600-9. 